\title{
Erratum: Case Report: VEXAS Syndrome: From Mild Symptoms to Life-Threatening Macrophage Activation Syndrome
}

\section{OPEN ACCESS}

Approved by:

Frontiers Editorial Office,

Frontiers Media SA, Switzerland

*Correspondence:

Frontiers Production Office production.office@frontiersin.org

Specialty section:

This article was submitted to

Autoimmune and

Autoinflammatory Disorders,

a section of the journal

Frontiers in Immunology

Received: 28 July 2021

Accepted: 28 July 2021

Published: 10 August 2021

Citation:

Frontiers Production Office (2021)

Erratum: Case Report: VEXAS Syndrome: From Mild Symptoms to

Life-Threatening Macrophage

Activation Syndrome.

Front. Immunol. 12:748756. doi: 10.3389/fimmu.2021.748756

\section{Frontiers Production Office ${ }^{\star}$}

Frontiers Media SA, Lausanne, Switzerland

Keywords: primary immunodeficiencies, autoinflammation, treatment reactions, myelodysplasia, ubiquitination

\section{An Erratum on:}

Case Report: VEXAS Syndrome: From Mild Symptoms to Life-Threatening Macrophage Activation Syndrome

Staels F, Betrains A, Woei-A-Jin FJSH, Boeckx N, Beckers M, Bervoets A, Willemsen M, Neerinckx B, Humblet-Baron S, Blockmans DE, Vanderschueren S and Schrijvers $R$ (2021). Front. Immunol. 12:678927. doi: 10.3389/fimmu.2021.678927

Due to a production error, an author name was incorrectly written as "Sherida Woei-A-Jin", which did not match the citation. The correct name is "F J Sherida H Woei-A-Jin". The publisher apologizes for this mistake.

The original version of this article has been updated.

Copyright $\odot 2021$ Frontiers Production Office. This is an open-access article distributed under the terms of the Creative Commons Attribution License (CC BY). The use, distribution or reproduction in other forums is permitted, provided the original author(s) and the copyright owner(s) are credited and that the original publication in this journal is cited, in accordance with accepted academic practice. No use, distribution or reproduction is permitted which does not comply with these terms. 